\title{
Identifikasi Penyakit Daun Jeruk Siam Menggunakan K-Nearest Neighbor
}

\section{Rifqi Hakim Ariesdianto ${ }^{1}$, Zilvanhisna Emka Fitri ${ }^{* 2}$, Abdul Madjid ${ }^{3}$, Arizal Mujibtamala Nanda Imron $^{4}$}

${ }^{1,2}$ Teknik Informatika, Jurusan Teknologi Informasi, Politeknik Negeri Jember, Indonesia ${ }^{3}$ Budidaya Tanaman Perkebunan, Jurusan Produksi Pertanian, Politeknik Negeri Jember, Indonesia ${ }^{4}$ Teknik Elektro, Fakultas Teknik, Universitas Jember, Indonesia Email: 1'rifqihakim99@gmail.com, ${ }^{2}$ zilvanhisnaef@polije.ac.id, ${ }^{3}$ abdul_madjid@polije.ac.id, ${ }^{4}$ arizal.tamala@unej.ac.id

\begin{abstract}
Abstrak
Jeruk siam adalah salah satu jeruk local yang mempunyai nilai jual yang tinggi di Indonesia. Tahun 2020, tingkat produksi jeruk siam mengalami penurunan menjadi 712.585 ton di Jawa Timur. Salah satu faktor utama yang menyebabkan menurunnya tingkat produksi jeruk siam yaitu serangan penyakit pada daun jeruk siam. Dua penyakit yang sering menyerang daun jeruk siam adalah penyakit kanker yang disebabkan oleh patogen Xanthomonas axonopodis pv.citri dan penyakit ulat peliang. Selama ini, pengamatan pada penyakit daun jeruk siam dilakukan secara manual menggunakan mata sehingga penentuan penyakit tersebut bersifat subyektif. Untuk mengatasi masalah tersebut dibuatlah sistem otomatis identifikasi daun jeruk siam sehat dan daun jeruk siam terserang penyakit dengan bantuan teknik computer vision. Tahapan penelitian yaitu pengumpulan citra daun jeruk, konversi warna, ekstraksi fitur warna dan tekstur serta klasifikasi K-Nearest Neighbor (KNN). Parameter fitur yang digunakan yaitu fitur warna GB, fitur tekstur (ASM, entropi dan kontras). Metode KNN mampu mengklasifikasi dan mengidentifikasi penyakit daun jeruk siam dengan akurasi sebesar $70 \%$ dengan variasi nilai $\mathrm{K}=21$.
\end{abstract}

Kata kunci: identifikasi, jeruk siam, pengolahan citra, penyakit daun, KNN.

\begin{abstract}
Siamese orange is one of the local oranges that has a high selling value in Indonesia. In 2020, the production level of Siamese oranges decreased to 712,585 tons in East Java. One of the main factors causing the decline in the production level of Siamese oranges is disease attacks on Siamese orange leaves. Two diseases that often attack the Siamese orange leaves are cancer caused by the pathogen Xanthomonas axonopodis pv.citri and caterpillar disease. So far, observations on siamese orange leaf disease have been done manually using the eyes so that the determination of the disease is subjective. To overcome this problem, an automatic identification system for healthy siamese orange leaves and siamese orange leaves was made with the help of computer vision techniques. The research stages are collection of orange leaf images, color conversion, color and texture feature extraction and K-Nearest Neighbor (KNN) classification. The feature parameters used are GB color features, texture features (ASM, entropy and contrast). The KNN method is able to classify and identify Siamese orange leaf disease with an accuracy of $70 \%$ with a variation of the value of $K=21$.
\end{abstract}

Keywords: identification, image processing, KNN, leaf disease, siamese orange.

\section{PENDAHULUAN}

Jeruk merupakan buah asli daerah tropis seperti india, indo-cina termasuk di Indonesia [1].Indonesia mempunyai tiga jenis jeruk lokal yang mempunyai nilai jual yang tinggi, salah satunya adalah jeruk siam. Jawa Timur merupakan salah satu provinsi penghasil jeruk dengan peningkatan tingkat produksi dari tahun 2016 hingga 2019. Tingkat produksi jeruk siam yaitu 837.370 ton pada 2016 kemudian meningkat menjadi 985.455 ton pada 2019, namun tingkat produksi jeruk siam menurun menjadi 712.585 ton pada 2020 [2]. Salah satu faktor utama yang menyebabkan menurunnya tingkat produksi jeruk siam yaitu serangan hama dan penyakit yang menyerang [3]. Dua penyakit yang sering 
menyerang daun jeruk siam adalah penyakit kanker yang disebabkan oleh patogen Xanthomonas axonopodis pv.citri dan penyakit ulat peliang[4]. Selama ini, pengamatan pada penyakit daun jeruk siam dilakukan secara manual menggunakan mata sehingga penentuan penyakit tersebut bersifat subyektif. Untuk mengatasi masalah tersebut dibuatlah sistem otomatis yang mampu mengidentifikasi daun jeruk siam sehat dan daun jeruk siam terserang penyakit dengan bantuan teknik computer vision. Prosesnya adalah pengenalan pola atau karakteristik dari citra daun jeruk siam.

Beberapa referensi yang digunakan pada penelitian ini, segmentasi metode otsu dan deteksi tepi canny pada citra daun jeruk tidak sehat pada tahun 2015[5]. Kemudian terdapat pembaharuan pada segmentasi menggunakan algoritma K-Means dan hasil segmentasi tersebut diklasifikasikan menggunakan K-Nearest Neighbor (KNN) dengan akurasi 90,83\% [6]. Pembaruan dilakukan pada proses konversi warna dari ruang warna RGB ke ruang warna HSV, setelah dilakukan konversi citra daun tersebut dilakukan proses segmentasi menggunakan teknik thresholding dan diklasifikasikan menggunakan Fuzzy K-Nearest Neighbor (FKNN) dengan akurasi sebesar 69\%[3]. Metode Support Vector Machine (SVM) digunakan untuk mengidentifikasi penyakit tanaman jeruk siam dan terjadi peningkatan akurasi menjadi 86,67\% [4]. Penerapan Gray Level Co-Occurrence Matrix (GLCM) digunakan identifikasi dan deteksi penyakit pada daun jeruk[7]. Berdasarkan penjabaran dari referensi diatas dapat disimpulkan bahwa metode KNN cocok untuk digunakan dalam mengklasifikasi sekaligus mengidentifikasi penyakit daun jeruk siam. Metode KNN adalah metode klasifikasi sederhana yang sistem pembelajarannya terawasi atau supervised learning, serta pengelompokkannya berdasarkan perhitungan jarak terdekat berdasarkan nilai K. Selain itu metode KNN digunakan dikarenakan pada penelitian lain mempunyai akurasi tinggi seperti klasifikasi abnormalitas sel darah putih untuk deteksi dini Myeloproliferative Neoplasms dengan akurasi sebesar 94,3\% [8]. Klasifikasi bakteri Infeksi Saluran Pernapasan Akut (ISPA) yang terdiri dari 5 kelas yaitu Staphylococcus aureus, Streptococcus pneumoniae, Corynebacterium diphteriae, Neisseria gonorrhoeae dan Mycobacterium tuberculosis dengan akurasi sebesar 91,67\% [9]. Pada penelitian ini dilakukan pembaruan yaitu konversi warna ke ruang GB, dimana ruang warna tersebut didapatkan dari hasil pengurangan komponen warna green dengan komponen warna blue pada ruang warna RGB. Kemudian dilakukan ekstraksi fitur tekstur menggunakan fitur dari Gray Level Co-Occurrence Matrix (GLCM) dan diklasifikasikan menggunakan metode klasifikasi K-Nearest Neighbor (KNN).

\section{METODE PENELITIAN}

Penelitian ini dilaksanakan di Kebun Jeruk Siam, Kecamatan Jombang, Kabupaten Jember dengan tahapan penelitian yaitu pengumpulan citra daun jeruk, konversi warna, ekstraksi fitur berdasarkan fitur tekstur dan klasifikasi KNN seperti Gambar 1.

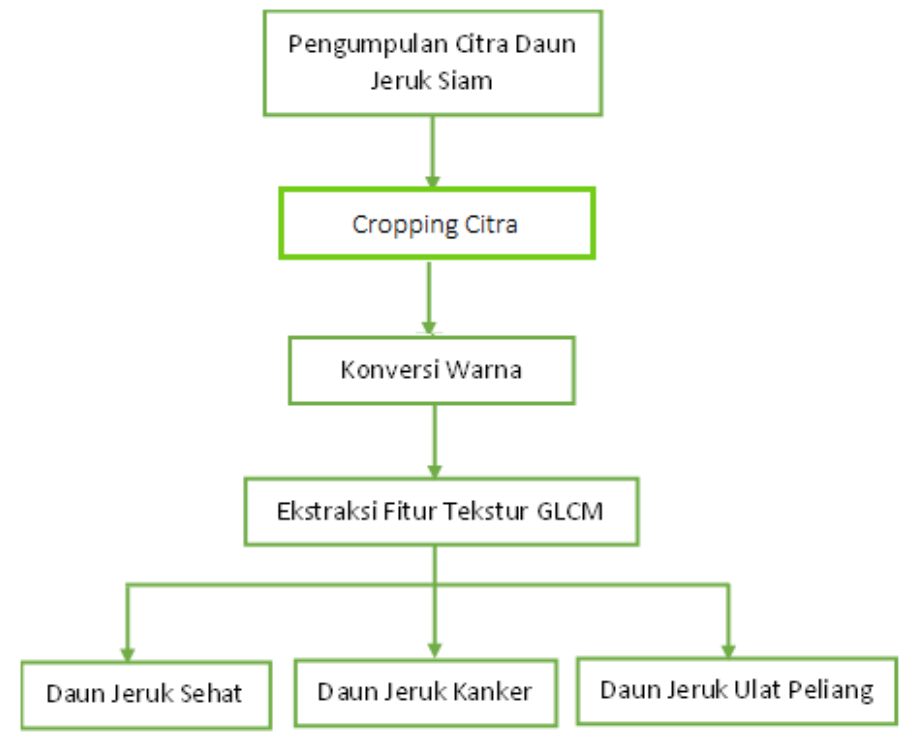

Gambar 1. Tahapan penelitian identifikasi penyakit daun jeruk siam 


\subsection{Pengumpulan citra daun jeruk siam}

Pada penelitian ini menggunakan peralatan seperti mini studio, tripod dan kamera smartphone dengan resolusi kamera sebesar $12 \mathrm{MP}$. Untuk pencahayaan, pemanfaatan cahaya matahari pada waktu 11.00 samapai dengan $14.00 \mathrm{WIB}$ untuk memperoleh kualitas citra daun jeruk siam optimal serta proses pengambilan juga terdapat pengaturan jarak antara obyek dan kamera yang telah terpasang pada tripod yaitu $20 \mathrm{~cm}$ terlihat pada Gambar 2.
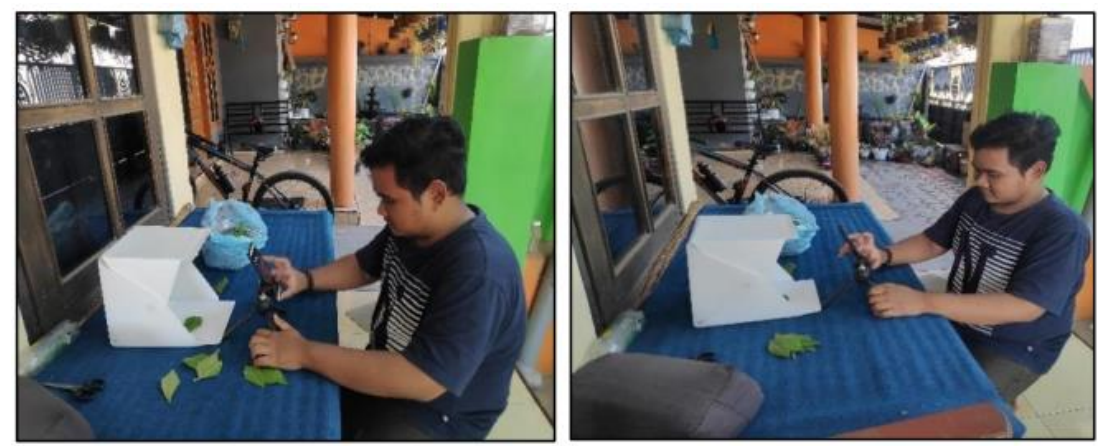

Gambar 2. Proses pengambilan citra daun jeruk siam

Jumlah data yang digunakan sebanyak 180 data citra jeruk yang terbagi menjadi data latih dan data uji. Pada penelitian ini terbagi menjadi 3 kelas yaitu 50 data citra jeruk siam sehat, 50 data citra jeruk siam penyakit kanker dan 50 data citra jeruk siam penyakit ulat peliang untuk data latih, sedangkan untuk data uji jumlah datanya terdiri dari 10 data pada masing-masing kelas seperti pada Gambar 3.

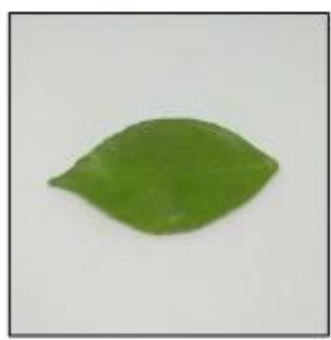

(a)

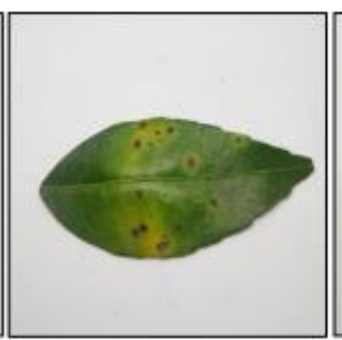

(b)

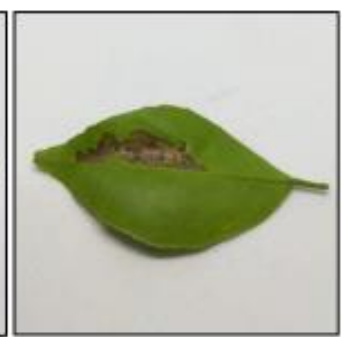

(c)

Gambar 3. (a) Citra jeruk siam normal, (b) Citra jeruk siam penyakit kanker dan (c) Citra jeruk siam penyakit ulat peliang

\subsection{Cropping Citra}

Sebelum dilakukan proses konversi warna, dilakukan dahulu proses pemotongan (cropping) untuk mengurangi beban komputasi [10]. Ukuran awal citra daun siam adalah 2340 x 4160 piksel kemudian dilakukan proses cropping menjadi ukuran yaitu 500 x 500 piksel seperti pada Gambar 4.

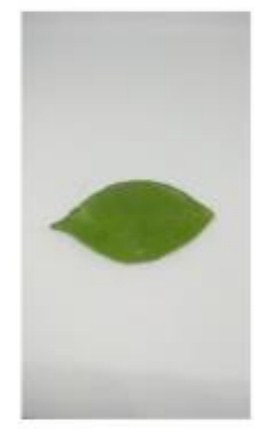

(a)

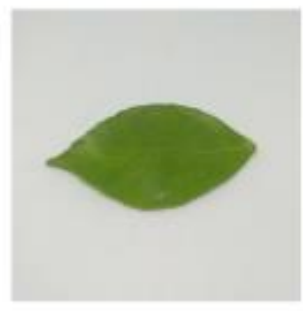

(b)

Gambar 4. (a) citra awal dan (b) citra setelah dilakukan proses cropping 


\subsection{Konversi Warna}

Pada proses konversi warna yang digunakan pada penelitian ini merupakan modifikasi pada ruang warna RGB. Pertama yang kita lakukan adalah proses pemecahan ruang warna RGB yaitu citra komponen red, citra komponen green dan citra komponen blue seperti Gambar 5. Setelah proses pemecahan komponen warna, dilakukan proses pengurangan pada masing-masing komponen warna, misal pengurangan komponen warna red dengan komponen warna green $(\mathrm{RG})$, pengurangan komponen warna blue dengan komponen warna green (BG), dst [11]. Pengurangan warna ini berfungsi untuk membentuk ruang warna baru seperti yang peneliti lakukan pada penelitian terdahulu namun menggunakan ruang warna CIELab [8].Hal tersebut juga berguna untuk mempermudah proses selanjutnya yaitu ekstraksi fitur.

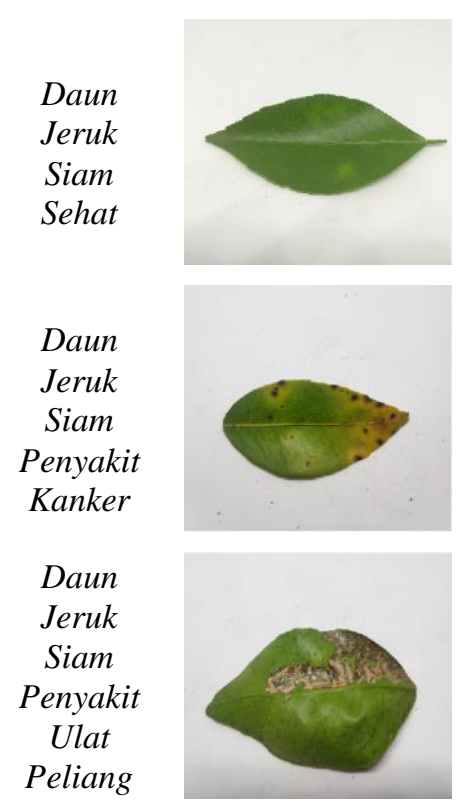

(a)
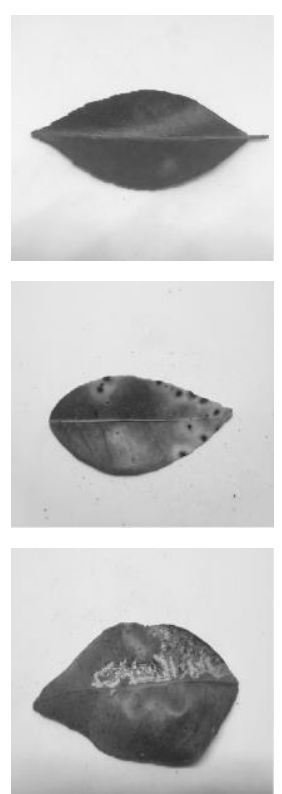

(b)
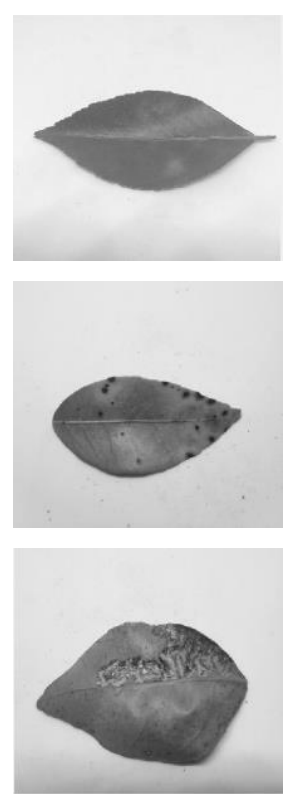

(c)

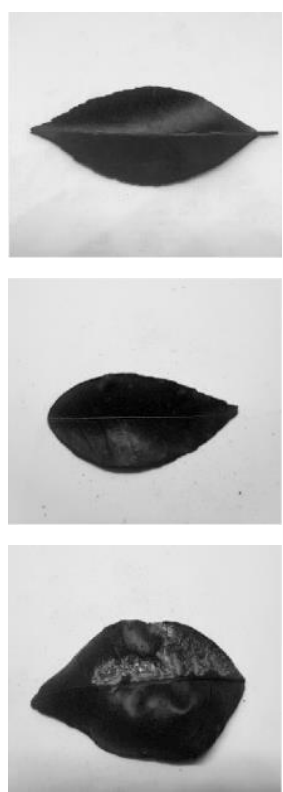

(d)

Gambar 5. (a) Citra Asli, (b) Citra Komponen Red, (c) Citra Komponen Green dan (d) Citra Komponen Blue

\subsection{Ekstraksi Fitur GLCM}

Gray Level Co-Occurrence Matrix (GLCM) merupakan salah satu ekstraksi fitur tekstur menggunakan perhitungan statistika orde kedua berdasarkan matriks derajat keabuan yang menggambarkan frekuensi kemunculan dua piksel dengan intensitas tertentu dalam jarak dan arah sudut tertentu [12]. Pada penelitian ini digunakan 3 fitur tekstur GLCM yaitu fitur Angular Second Moment (ASM), Kontras dan Entropi dengan persamaan rumus sebagai berikut :

$$
\begin{aligned}
& \text { ASM }=\sum_{i=1}^{L} \sum_{j=1}^{L} A_{i, j}^{2} \\
& \text { Kontras }=\sum_{n=1}^{L} n^{2}\left(\sum_{|i-j|=n} A_{(i, j)}\right) \\
& \text { Entropi }=\sum_{i=1}^{L} \sum_{j=1}^{L} A_{(i, j)} \log \left(A_{(i, j)}\right)
\end{aligned}
$$

Dimana A(i,j) adalah matriks co-occurrence dari citra yang telah diekstraksi 


\subsection{Klasifikasi K-Nearest Neighbor}

Metode K-Nearest Neighbor (KNN) adalah metode klasifikasi yang mengklasifikasikan data berdasarkan nilai $\mathrm{K}$ pada perhitungan jarak terdekat, perhitungan tersebut biasanya menggunakan persamaan rumus perhitungan jarak Euclidean[9] :

$$
E D\left(A_{i}, A_{j}\right)=\sqrt{\sum_{r=1}^{n}\left(A_{i r}-A_{i j}\right)^{2}}
$$

Dimana $\mathrm{A}_{\text {ir }}$ adalah data uji dan $\mathrm{A}_{\mathrm{ij}}$ adalah data latih

\section{HASIL DAN PEMBAHASAN}

Pada tahapan proses konversi warna, sebelumnya dilakukan proses pemecahan komponen warna pada ruang warna RGB (citra asli) dengan tujuan untuk melakukan proses segmentasi dan mempermudah proses ekstraksi fitur. Setelah proses pemecahan tersebut, dilakukan proses pengurangan antara komponen warna untuk mendapatkan ruang warna baru, hasil proses pengurangan tersebut ditunjukkan pada Gambar 6.
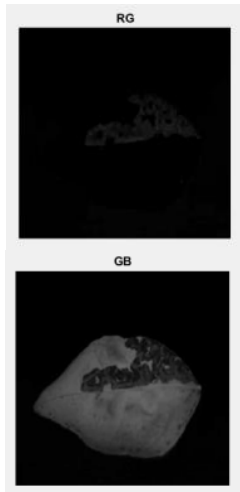
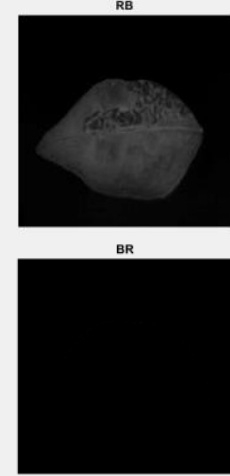
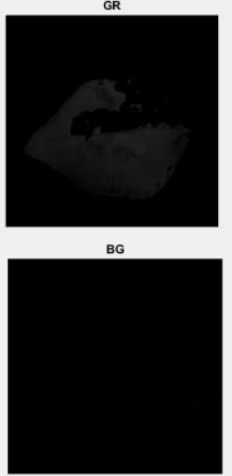

Gambar 6. Hasil pengurangan komponen warna pada citra jeruk siam ulat peliang

Gambar 6 menunjukkan bahwa hasil pengurangan komponen warna pada ruang warna RGB dapat menghasilkan ruang warna baru yaitu RG, RB, GR, GB, BR dan BG. Berdasarkan gambar tersebut ruang warna yang paling merepresentasikan tekstur paling baik adalah ruang warna GB yang merupakan hasil pengurangan komponen warna green dengan komponen warna blue. Sedangkan bila dibandingkan dengan ruang warna RB dapat dilihat pada Gambar 7.

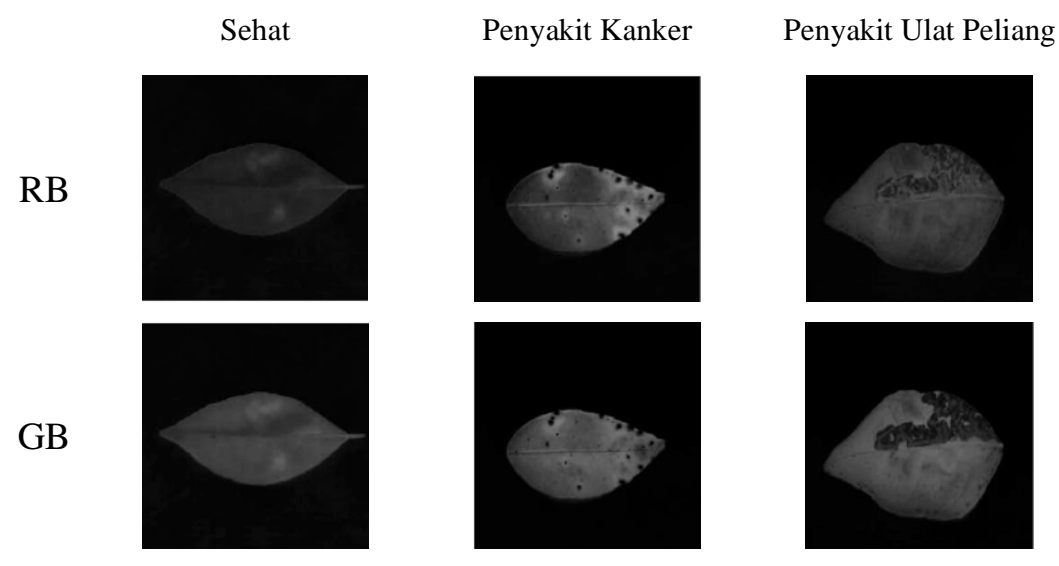

Gambar 7. Perbandingan citra ruang warna RB dan GB pada masing-masing kelas 
Berdasarkan hasil pada Gambar 7, dapat dilihat perbedaan citra ruang warna RB dan GB. Pada ruang warna $\mathrm{RB}$, hanya citra daun jeruk siam penyakit kanker yang teksturnya terlihat jelas sedangkan pada kelas daun sehat tidak telihat jelas dan pada kelas penyakit ulat peliang, terksturnya telihat namun masih samar. Hal ini berbeda pada ruang warna GB, dimana setiap kelas terlihat jelas tekstur daunnya, maka citra ruang warna GB dipilih untuk diproses pada ekstraksi fitur tekstur GLCM. Fitur yang digunakan pada penelitian ini berjumlah 13 fitur yang terdiri dari fitur warna GB, fitur tekstur ASM, kontras dan entropi pada sudut $0^{\circ}, 45^{\circ}, 90^{\circ}$ dan $135^{\circ}$. Salah satu contoh hasil ekstraksi fitur pada sudut $90^{\circ}$ data latih. ditunjukkan pada Tabel 1.

Tabel 1. Contoh nilai fitur data latih sudut $90^{\circ}$

\begin{tabular}{ccccc}
\hline GB & ASM & Entropi & Kontras & Kelas \\
\hline 5,462 & 0,157 & 2,439 & 0,173 & Sehat \\
12,168 & 0,220 & 2,532 & 0,270 & Sehat \\
8,097 & 0,168 & 2,508 & 0,138 & Sehat \\
12,267 & 0,143 & 2,836 & 0,279 & Sehat \\
17,166 & 0,142 & 3,215 & 0,887 & Kanker \\
18,426 & 0,084 & 3,649 & 0,919 & Kanker \\
14,091 & 0,094 & 3,364 & 0,872 & Kanker \\
17,382 & 0,081 & 3,760 & 1,056 & Kanker \\
8,760 & 0,129 & 2,820 & 0,245 & Ulat Peliang \\
7,675 & 0,150 & 2,671 & 0,211 & Ulat Peliang \\
9,626 & 0,107 & 2,854 & 0,168 & Ulat Peliang \\
8,939 & 0,108 & 2,861 & 0,176 & Ulat Peliang \\
\hline
\end{tabular}

Jumlah data yang digunakan sebanyak 180 data citra jeruk siam yang terbagi menjadi 150 data latih dan 30 data uji. Nilai fitur yang didapatkan pada proses ekstraksi fitur merupakan input pada metode KNearest Neighbor. Untuk mengklasifikasikan data misalnya kita punya data seperti Tabel 2, langkah awal yang dilakukan adalah mencari nilai jarak Euclidean dari masing-masing data latih (Tabel 1) menggunakan persamaan rumus (4) kemudian diurutkan berdasarkan nilai jarak terkecil sampai jarak terbesar seperti pada Tabel 3. Selanjutnya menentukan nilai K dan pengklasifikasian berdasarkan nilai $\mathrm{K}$ serta data tersebut akan diklasifikasikan pada kelas prioritas yang masuk pada nilai $\mathrm{K}$.

\begin{tabular}{ccccc}
\multicolumn{4}{c}{ Tabel } & 2. Data yang belum diklasifikasikan \\
\hline GB & ASM & Entropi & Kontras & Kelas \\
\hline 16,731 & 0,258 & 2,686 & 0,442 & - \\
\hline
\end{tabular}

Tabel 3. Hasil perhitungan jarak Euclidean

\begin{tabular}{cccc}
\hline Urutan & Jarak Euclidean (ED) & Nilai Jarak Euclidean & Kelas \\
\hline 1 & ED5 & 0,682 & Kanker \\
2 & ED8 & 1,983 & Kanker \\
3 & ED7 & 3,310 & Kanker \\
4 & ED6 & 4,055 & Kanker \\
5 & ED4 & 20,191 & Sehat \\
6 & ED2 & 20,883 & Sehat \\
7 & ED11 & 50,811 & Ulat Peliang \\
8 & ED12 & 61,465 & Ulat Peliang \\
9 & ED9 & 63,618 & Ulat Peliang \\
10 & ED3 & 74,656 & Sehat \\
11 & ED10 & 82,089 & Ulat Peliang \\
12 & ED1 & 137,134 & Sehat \\
\hline
\end{tabular}

Misalnya nilai $\mathrm{K}$ ditentukan bernilai 3, hal ini disesuaikan dengan jumlah kelas dari data yang diklasifikasikan. Berdasarkan hasil perhitungan jarak Euclidean (Tabel 3) pada data latih (Tabel 1) 
didapatkan bahwa ED5, ED8 dan ED7 adalah jarak Euclidean untuk kelas daun jeruk siam penyakit kanker, maka data pada Tabel 2 diklasifikasikan menjadi kelas daun jeruk siam penyakit kanker. Sementara pada penelitian ini ditentukan 5 kali pada nilai $\mathrm{K}$ yaitu 19, 21, 23, 25 dan 27, penentuan tersebut digunakan untuk menentukan akurasi dari metode K-Nearest Neighbor dalam mengklasifikasi dan mengidentifikasi penyakit daun jeruk siam. Hasil akurasi metode KNN ditunjukkan pada Tabel 4.

Tabel 4. Hasil akurasi sistem berdasarkan variasi nilai $\mathrm{K}$

\begin{tabular}{cc}
\hline Nilai K & Akurasi (\%) \\
\hline 19 & 60 \\
21 & 70 \\
23 & 63,33 \\
25 & 60 \\
27 & 60 \\
\hline
\end{tabular}

Berdasarkan hasil yang ditunjukkan pada Tabel 4, maka akurasi sistem terbaik yaitu $70 \%$ dengan nilai $\mathrm{K}=21$, hal ini dikarenakan banyak data pada masing-masing kelas diklasifikasikan tidak sesuai dengan target yang diinginkan, Perhitungan akurasi pengujian pada 30 data uji dihitung berdasarkan confusion matrix dan ditunjukkan pada Tabel 5.

Tabel 5. Confusion matrix pada pengujian sistem

\begin{tabular}{cccl}
\hline & \multicolumn{2}{c}{ Hasil Klasifikasi } & \multicolumn{1}{c}{ Target } \\
\cline { 1 - 3 } Daun Sehat & Daun Penyakit Kanker & Daun Penyakit Ulat Peliang & \multicolumn{1}{c}{ Daun Sehat } \\
\hline 7 & 2 & 1 & Daun Penyakit Kanker \\
3 & 6 & 1 & Daun Penyakit Ulat Peliang \\
\hline & 2 & 8 & 21 \\
& \multirow{2}{*}{ Akurasi sistem $=\frac{7+6+8}{30} \times 100 \%=\frac{2100 \%=70 \%}{30} \times 10$}
\end{tabular}

Tabel 5 menunjukkan bahwa masih banyak untuk kelas daun jeruk siam sehat diklasifikasikan sesuai dengan target yaitu 7 data dan salah diklasifikasikan sebagai kelas daun jeruk siam penyakit kanker sebanyak 2 data serta sebagai kelas daun jeruk siam penyakit ulat peliang sebanyak 1 data. Untuk kelas daun jeruk siam penyakit kanker diklasifikasikan benar sesuai dengan target sebanyak 6 data dan salah diklasifikasikan sebagai kelas daun jeruk siam sehat sebanyak 3 data serta sebagai kelas daun jeruk siam penyakit ulat peliang sebanyak 1 data. Untuk kelas daun jeruk siam penyakit ulat peliang diklasifikasikan benar sesuai dengan target sebanyak 8 data dan salah diklasifikasikan sebagai kelas daun jeruk siam penyakit kanker sebanyak 2 data.

\section{DISKUSI}

Berdasarkan hasil tingkat akurasinya, KNN cukup baik dalam mengklasifikasi dan mengidentifikasi penyakit daun jeruk siam. Kesalahan-kesalahan KNN dalam mengklasifikasikan citra daun jeruk siam dikarenakan masih banyak citra yang memiliki kesamaan nilai parameter pada masingmasing kelas. Kemiripan nilai ini dimungkinkan konversi warna ke ruang GB belum optimal sehingga perlu dibandingkan dengan konversi ke ruang warna lain misalnya ke citra negatif, kemudian untuk memperjelas batasan pada obyek penyakitnya dibutuhkan operasi deteksi tepi. Penambahan fitur juga diperlukan untuk menambah keberagaman parameter dari masing-masing kelas sehingga membantu metode dalam mengidentifikasi serta mengenali pola penyakit daun jeruk siam. Selain itu perlu juga dibandingkan menggunakan metode klasifikasi yang lain untuk mendapatkan hasil akurasi yang lebih baik daripada KNN.

\section{KESIMPULAN}

Penelitian ini dilakukan dengan menggunakan 150 data latih dan 30 data uji yang terdiri dari tiga kelas yaitu kelas daun jeruk siam sehat, kelas daun jeruk siam penyakit kanker dan kelas daun jeruk 
siam penyakit ulat peliang. Berdasarkan hasil klasifikasi pada sistem didapatkan bahwa metode klasifikasi K-Nearest Neighbor (KNN) mampu mengklasifikasi dan mengidentifikasi penyakit daun jeruk siam dengan akurasi sebesar $70 \%$ dengan variasi nilai $\mathrm{K}=21$. Kesalahan klasifikasi disebabkan banyak kemiripan nilai parameter pada masing-masing kelas. Maka dibutuhkan perbaikan dan penambahan fitur untuk mengidentifikasi serta mengenali pola penyakit daun jeruk siam. Selain itu perlu membandingkan dengan metode klasifikasi yang lain sehingga mendapatkan metode klasifikasi yang paling baik dan akurat dalam mengklasifikasi dan mengidentifikasi penyakit daun jeruk siam.

\section{DAFTAR PUSTAKA}

[1] K. D. Sitanggang, Kultur Antera Jeruk, I. Malang: CV Literasi Nusantara Abadi, 2021.

[2] BPS, "Produksi Tanaman Buah Jeruk Siam/Keprok," Badan Pusat Statistik, p. 2012, 2019.

[3] F. R. Lestari, J. Y. Sari, Sutardi, and I. Purwanti, "Deteksi Penyakit Tanaman Jeruk Siam Berdasarkan Citra Daun," Seminar Nasional Teknologi Terapan Berbasis Kearifan Lokal (SNT2BKL), no. December, pp. 276-283, 2018.

[4] F. R. Lestari et al., "Identifikasi Penyakit Tanaman Jeruk Siam Menggunakan Metode M-Svm," Ruang Publikasi Udinus, pp. 441-448, 2019.

[5] M. Widyaningsih, "Segmentasi Canny Dan Otsu pada Citra Daun Jeruk Tidak Sehat," in SEMNASKIT, 2015, pp. 43-48.

[6] F. G. Febrinanto, C. Dewi, and A. T. Wiratno, "Implementasi Algoritme K-Means Sebagai Metode Segmentasi Citra Dalam Identifikasi Penyakit Daun Jeruk," Jurnal Pengembangan Teknologi Informasi dan Ilmu Komputer (J-PTIIK) Universitas Brawijaya, vol. 2, no. 11, pp. 5375-5383, 2018.

[7] R. Sharma and S. Kaur, "Convolution Neural Network based Several Orange Leave Disease Detection and Identification Methods: A Review," Proceedings of the 2nd International Conference on Smart Systems and Inventive Technology, ICSSIT 2019, no. Icssit, pp. 196-201, 2019, doi: 10.1109/ICSSIT46314.2019.8987744.

[8] Z. E. Fitri, L. N. Y. Syahputri, and A. M. N. Imron, "Classification of White Blood Cell Abnormalities for Early Detection of Myeloproliferative Neoplasms Syndrome Based on KNearest Neighborr," Scientific Journal of Informatics, vol. 7, no. 1, pp. 136-142, 2020, doi: 10.15294/sji.v7i1.24372.

[9] Z. E. Fitri, L. N. Sahenda, P. S. D. Puspitasari, P. Destarianto, D. L. Rukmi, and A. M. N. Imron, "The Classification of Acute Respiratory Infection ( ARI ) Bacteria Based on K-Nearest Neighbor," Lontar Komputer : Jurnal Ilmiah Teknologi Informasi, vol. 12, no. 2, pp. 91-101, 2021.

[10] A. M. Nanda Imron and Z. E. Fitri, "A Classification of Platelets in Peripheral Blood Smear Image as an Early Detection of Myeloproliferative Syndrome Using Gray Level Co-Occurence Matrix," Journal of Physics: Conference Series, vol. 1201, no. 1, 2019, doi: 10.1088/17426596/1201/1/012049.

[11] Z. E. Fitri et al., "Penerapan Fitur Warna dan Tekstur untuk Identifikasi Kerusakan Mutu Biji Kopi Arabika (Coffea Arabica) di Kabupaten Bondowoso," Jurnal Ilmiah Teknologi Informasi Asia, vol. 15, no. 2, 2021.

[12] Z. E. Fitri, U. Nuhanatika, A. Madjid, and A. M. N. Imron, "Penentuan Tingkat Kematangan Cabe Rawit (Capsicum frutescens L.) Berdasarkan Gray Level Co-Occurrence Matrix," Jurnal Teknologi Informasi dan Terapan, vol. 7, no. 1, pp. 1-5, 2020, doi: 10.25047/jtit.v7i1.121. 